\title{
Reklam Ajansında Kadın Olmak: Reklam Sektörü ve Toplumsal Cinsiyet
}

\author{
Barış Kara \\ Dr. Öğr. Üyesi \\ Galatasaray Üniversitesi Illetişim Fakültesi \\ bkara@gsu.edu.tr \\ ORCID: 0000-0002-0665-0886 \\ İpek Özgen \\ ipekozgen94@gmail.com \\ ORCID: 0000-0002-9326-3824
}

\section{Abstract \\ Being a Woman in an Advertising Agency: The Advertising Industry and Gender}

While the recent increase in research in gender studies reflected the social structure and gender practices, it also created a repetitive academic accumulation. Especially, numerous studies in the field of communication studies that examine media output in order to study gender representation and discourse analysis constituted that repetitive accumulation. At that point, the main starting point of this study is not to examine the content of advertisements but to understand the gender position and problems of women working in the advertising industry as the creators of advertisements. For this purpose, in-depth interviews were conducted with 15 female advertisers from different departments. According to the interviews conducted, due to cultural construction, gender inequalities and patriarchal structure are also experienced within advertising agencies. As a social phenomenon, the agents of this production and reproduction of gender inequality are not only men but also women because of internalized gender codes and behaviours.

keywords: gender, advertising, advertising industry, woman 


\section{Résumé}

\section{Être une femme dans une agence de publicité : l'industrie de la publicité et le genre}

L'augmentation quantitative que l'on observe récemment dans les recherches consacrées aux études de genre reflétant la structure et les pratiques sociales, semble produire une accumulation académique qui ne peut échapper à la répétition. Les études de représentation et les analyses de discours relatives aux médias, réalisées dans le domaine de communication peuvent, en particulier, être considérées comme des exemples d'une telle accumulation. Au lieu d'examiner le contenu des publicités, le point de départ de cette recherche serait de comprendre le positionnement et les problèmes des femmes qui travaillent dans l'industrie publicitaire par rapport aux questions de genre. Afin de réaliser cet objectif, des entretiens approfondis ont été menés avec 15 femmes publicitaires issues de différents départements. Les résultats ont montré que les problèmes liés à l'inégalité des genres et à la structure patriarcale de la société qui sont des constructions culturelles, persistent également au sein des agences de publicité. Il est, par ailleurs, constaté que les agents impliqués dans ce processus de production et de reproduction sociales ne sont pas seulement des hommes mais aussi des femmes en raison de codes et de comportements de genre intériorisés.

mots-clés: le genre, la publicité, l'industrie publicitaire, les femmes

\section{Öz}

Literatürde toplumsal cinsiyet araştırmalarının son yıllardaki niceliksel artışı, toplumsal yapı ve pratikleri yansıtsa da kimi noktalarda kendini tekrar eden bir akademik birikime yol açtığı görülmektedir. Özellikle iletişim alanında yapılan, medya çıktıları üzerinden gerçekleştirilen temsil ve söylem incelemeleri bu duruma bir örnek olarak verilebilir. Bu araştırmada temel çıkış noktası reklam metinlerinin içerik olarak incelenmesi yerine bu metinleri oluşturan reklam sektöründe çalışan kadınların reklam ajansları özelinde toplumsal cinsiyete bağı konumlarını ve sorunlarını anlamaya çalışmaktır. Bu amaçla farkı departmanlardan 15 kadın reklamcı ile derinlemesine görüşmeler gerçekleştirilmiştir. Bu görüşmeler sonucunda kültürel bir inşanın sonucu olan toplumsal cinsiyet sorunlarının ve bağlantılı eril yapılanmanın reklam ajansları dahilinde de yaşandığı tespit edilmiştir. Toplumsal bir olgu olarak bu üretim ve yeniden üretimin faillerinin sadece erkekler değil, içselleştirilmiş kod ve davranışlarla kadınlar da olduğu görülmüştür.

anahtar kelimeler: toplumsal cinsiyet, reklam, reklam sektörü, kadın 


\section{Giriş}

Ekonomik yapı ve kurumlar dahilinde ele alınan kadın istihdamı ve çalışma yaşamı, toplumsal bir sonuç olarak cinsiyet eşitsizlikleri bağlamında uzun süredir incelenmektedir. Akademik literatürde gerek niceliksel gerekse niteliksel olarak gerçekleştirilen birçok araştırma, iş yaşamında kadın istihdamı konusunda dünya genelinde ve Türkiye'de halen çözülememiş / çözülmemiş hatta kemikleşmiş birçok sorun olduğunu göstermektedir. Her ne kadar bu veriler ve belirlenmiş ana sorunlar dünya genelinde benzer belli başlıkları ortaya koysa da, Türkiye'de mevcut durumda halen çok fazla yol kat etmeye intiyaç duyulduğunu göstermektedir.

Ekonomi ve toplumsal cinsiyet eşitliği konusunda kadınların karşılaştığı küresel ve ulusal bazda temel sorunlar şu şekilde sıralanabilir: iş yaşamına katılım ve istihdam, çalışma hakları, kayıtdışı işçilik, karar alma mekanizmalarına katıım, ücret açı̆̆ı, ev işleri ve bakım hizmetleri, eğitim durumuna bağıı istihdam, toplumsal cinsiyete dayalı işbölümü ve mesleki ayrışmalar konularında var olan eşitsizlikIer (Aile ve Sosyal Politikalar Bakanlığı, 2018; İktisadi Kalkınma Vakfı, 2019; ILO, 2018; İşkur, 2015; WEForum, 2020; KOÇ-KAM, 2019).

Literatürde reklam ve reklamclık sektörünü konu alan çalışmaların çoğu reklamlarda toplumsal cinsiyet söylemleri ve kadın temsilleri gibi önemli konuları araştıırıen, bu temsilleri ve söylemleri yaratan, stratejileri ve hedef kitleleri belirleyen reklam üreticileri göz ardı edilmiştir. Ancak kurumsal yapı dahilinde oluşan toplumsal cinsiyete dayalı iş bölümünü ve çalışma yaşamını anlamak, kadın çalışanların toplumsal cinsiyetle ilgili koşullarını ve görüşlerini tespit etmek önemli bir konu olarak karşımıza çıkmaktadır.

Araştırmada hizmet sektörü ve kültürel üretimin bir parçası olarak Türkiye'de İstanbul ilinde reklam sektöründe yer alan ve klasik ajans olarak adlandırılan "Yaratıcı/Tam Hizmet Reklam Ajansları"nda çalışan kadınların toplumsal cinsiyet bağlamında konum ve sorunlarının incelenmesi amaçlanmıştır. Kuramsal yaklaşım toplumsal cinsiyetin bir inşa olarak ele alındığı kavramlarla desteklenmiş ve reklam sektöründe konu ile ilgili tespit edilen yapısal sorunlar ortaya konulmuştur.

\section{Toplumsal Cinsiyetin İnşası ve Reklam Sektörü}

Cinsiyet eşitsizliklerinin toplumsal bağlam ve nedenlerinin anlaşılması, belli kavram ve/veya kavram setlerinin açıklanmasını gerektirmektedir. Bu şekilde araştırmaya konu olan reklam sektöründe kadın istihdamının durumunun ve sorunlarının daha görünür hale getirilmesi amaçlanmaktadır. Judith Butler (2014 s.50), cinsiyet ve toplumsal cinsiyet kavramlarının ayrımını açıklarken, biyolojik özelliklere bağlı olarak tanımlanan cinsiyete karşın kültürel olarak inşa edilen toplumsal cinsiyetin cinsiyet kadar sabit olmadığını belirtmiştir. Biyolojik cinsiyetten kaynaklanan toplumsal ve kültürel tanımlar (Dökmen, 2010, s.29) doğrultusunda şekillenen toplumsal cinsiyet, kadın olmanın ve erkek olmanın işaret ettiği davra- 
nış, özellik ve rollerin benimsenmesini gerektirmektedir. Tüm bu roller ve davranışlar ise toplumsallaşma süreçlerinde öğrenilmektedir.

Bu açıdan, toplumsal cinsiyet kavramlarının belirlenmesinde kurumlar büyük bir rol oynamaktadır. Aynı zamanda Acker (1990 s. 140)'a göre tüm toplumsal yapıların ve kurumların kurucu ögelerinden biri olan toplumsal cinsiyet de kurumlar arası ilişkilerde belirleyici olmaktadır. Ekonomik yapı bağlamında çalışma yaşamında ve bağlantılı iş yerinde organizasyonel mantığın ve pratiklerin de temelini oluşturmaktadır (Padavic, 1991). Bu bağlamda, çevre içinde oluşan ve toplumsallaşma yoluyla bireyler tarafından öğrenilen ve benimsenen toplumsal cinsiyet "toplumsal bir inşa" (Holmes, 2007) olarak tanımlanmaktadır. Gerek kişilerarası ilişkilerde gerekse kurumlar bazında konunun bu yönde ele alınması; kişisel, ilişkisel ve yapısal bağlamda mevcut durum ve sorunları daha anlaşıır kılmaktadır.

Salminen-Karlsson (2006) "durumsal öğrenme" (situated learning) ve "cinsiyet icrası" (doing gender) kavram / teorileri bağlamında organizasyonel pratikler içerisinde toplumsal cinsiyet-bilgi ve kimliğin etkileşim ve pratik yoluyla birlikte üretildiğini belirtmektedir. Lave and Wenger'a ait olan teori, öğrenmeyi söz konusu pratiklerin bir parçası olarak ele almaktadır. Bu noktada topluluğa katıım ve topluluğun gerçek bir üyesi olmanın "öğrenilmesi" ve o kimliğe sahip olmak bireylerin başlıca amacı haline gelmektedir. Salminen-Karlsson (2006) "durumsal öğrenme" kavramının öğrenmeyi ilgili topluluğun içerisinde toplumsallaşma süreciyle tanımladığını, aynı yolla öğrenilen toplumsal cinsiyeti de kapsadığını savunmaktadır. Insan etkileşimine odaklanan teoriye göre bu etkileşimde toplumsal cinsiyet önemli bir rol oynamaktadır. Diğer yandan West ve Zimmerman (1987)'ın öne sürdüğü "cinsiyet icrası" kavramı toplumsal cinsiyetin organizasyonel pratik ve günlük hayat içerisinde sürekli olarak inşa edildiğini; bu şekilde toplumsal cinsiyet ayrımının bireylerin davranışları ve kendilerini ifade etme yollarıyla somutlaştığını ve meşrulaştıııdığını, böylece kendi kadın ve erkek kimliklerini diğerlerine kanıtladıklarını öne sürmektedir (Salminen-Karlsson, 2006; Padavic, 1991).

Organizasyonlar içerisinde toplumsallaşan bireyler için kimlik, kimlik oluşturmak ve organizasyonun normlarına uygun bu kimliklerin sergilenmesi organizasyona katılımdan itibaren başlayan bir öğrenme süreciyle gerçekleşmektedir. Işsyeri gibi uygulama topluluklarında bireylerin "günlük pratiklere katılım yoluyla" bu kimlikleri öğrendiği (Salminen-Karlsson, 2006) ve bu katılımın bireysel değil ancak kolektif bir süreç olduğu belirtilmektedir (McLeod vd., 2011). Bireyler söz konusu yapıya katıldıkları andan itibaren topluluğun "cinsiyetlendirilmiş bir üyesi" olmakta ve onlardan topluluğun toplumsal cinsiyet rollerine uygun davranmaları beklenmektedir. Bu noktada bireyler içinde bulundukları topluluğun bir üyesi olabilmek ve kendi kimliklerinin meşruluğunu kanıtlamak için bir mücadele vermektedirler (Salminen-Karlsson, 2006 ss. 37 - 38).

Acker (1990), işgücü piyasasının yapısı ve işyerindeki ilişkilerin her zaman toplumsal cinsiyet sembollerinden, toplumsal cinsiyet kimliği süreçlerinden ve 
kadın ve erkek arasındaki materyal eşitsizliklerden etkilendiğini belirtmektedir. İşyeri ve toplumsal cinsiyetin incelenmesinin gerekliliğini üç temel sebeple açıklamıştır: ücretli ve ücretsiz işler de dahil olmak üzere işyerinde toplumsal cinsiyet ayrımcılığının ve buna bağlı olarak kadın ve erkek arasındaki gelir ve statü eşitsizliğinin örgütsel olarak yaratılıyor oluşu, bu süreçleri anlamanın toplumsal cinsiyet eşitsizliğinin anlaşılması için gerekli olması ve son olarak geniş çapta yayılan toplumsal cinsiyet imgelerinin örgütlerde üretilmesi ve yeniden üretilmesi. Padavic (1991) sosyalleşme yoluyla inşa ve yeniden inşa edilen, benimsenen cinsiyet rollerinin iş yerinin dışından getirildiğini ve iş yerinde yeniden üretildiğini belirtmiştir.

Reklam sektörünün kurum kültürü, yapısı ve iş bölümü pratiklerinin kendine has özellikleri de içerdiğini kabul ederek, yukarıda açıklanan inşa süreçlerinin dışında kalmadığı belirtilebilir. Kadın istihdamının yüksek olması sebebiyle reklam sektörü "kadınlaşmış" bir alan olarak adlandırılmakta ancak sektörde cinsiyet ayrımcıı̆̆ının mevcut olduğu ve kadınların özellikle karar verici ve yönetici pozisyonlarında yeterince yer alamadığı görülmektedir (Mallia ve Windels, 2015; van Het Hof ve Hoştut, 2016; García-González ve Piñeiro-Otero, 2011; Arnberg ve Svanlund, 2017). Ayhan (2010, s. 247) bu durumu "sözde kadınlaşma" (pseudo-feminization) kavramıyla açıklamıştır. Kadın reklamcılar, reklamcılık iş gücünün büyük çoğunluğunu temsil etmelerine rağmen dikey ve yatay bir ayrımcılığa maruz kalmaktadır ve bu durumun başlıca sonuçları kadınlar ve erkekler arasında eşit olmayan çalışma şartları ve gelir farklııklarıdır. Bu durum toplumsal cinsiyet tanımlarının işyerinde dikey ayrımclık şeklinde kendisini göstermesi olarak adlandırılabilir.

Gregory (2009), "erkek soyunma odası" (male locker room) metaforunu kullanarak reklam endüstrisindeki özellikle yüksek pozisyonlardaki erkek tekelleşmesini incelemiş̧ir. Sektördeki erkek egemen yapı birçok araştırmacı tarafından vurgulanarak incelenmişken, bunun sebepleri arasında mevcut yöneticilerin çoğunluğunun erkeklerden oluşması, başta yaratıcı departmanlarda başarıı olmak için gerekli birçok karakter özelliği ve becerinin erkeklik ile özdeşleştirilmesi gösterilmiştir. "Erkek soyunma odası" metaforu, hem reklam ajansı içerisindeki çalışma ortamı hem de ajans müşterisi olan reklamverenler arasındaki sektörün bir parçası olarak kabul edilen gayri resmi iletişim yoluyla iş yapma şeklini vurgulamaktadır. Erkeklerin arasında eril iletişim kodlarının kullanıldığı bu süreçte, iş görüşmelerinin ve iş dünyasının resmi "networking" pratikleri bir kenara bırakılmakta ve reklamcıların dünyasına has sosyalleşme ve iletişim ritüelleri kullanılmaktadır (Gregory, 2009, s. 325). Böylece erkeklerin yine kendi hemcinsleri ile "erkek hemcins toplumsallaşması"ndan (male homosociability) kaynaklanan erkek egemen bir ortam ortaya çıkmaktadır.

Iş bölümü açısından reklam ajansı içinde bulunan departmanlar bağlamında kadın ve erkek çalışan yoğunluğunun farklılaştığı ve bir tür alan ayrımcılığı olduğu görülmektedir. Kadın ve erkeklere toplumsal cinsiyet tanımları kapsamında farklı yetenek ve özelliklerin atfedilmiş olması, çeşitli yetenek ve karakter özelliklerinin "eril" ve "dişil" olarak sınıflandırıması, özellikle kadınların mesleki olarak kısıtlan- 
masına sebep olmaktadır. Bunun yanında kadınların fiziksel görünümlerine dair beklentiler, daha çok sosyal ilişkilerde beceri ve ikna kabiliyeti gerektiren müşteri ilişkileri departmanı ile anılmalarına sebep olmaktadır (García-González ve Piñeiro-Otero, 2011; Thompson-Whiteside vd., 2020). "Erkekler kulübü" (boys club) olarak adlandırılan yaratıcı departmanlarda (Kuc, 2017) var olmak ve yükselmek ise kadın reklamcılar için büyük ve zorlu bir mücadele haline gelmektedir. Mallia (2009), özellikle yaratıcı departmanlarda kadınların kendilerine yer bulamaması ya da bir süre sonra kaybolmasını cam tavan ile açıklamıştır. "Başarılı olamama", yeteneksizlik ya da az çalışma değil; toplumsal cinsiyetlere atfedilmiş yetenekler, roller ve sosyal hayat içinde birincil meşguliyet olarak kadın ve erkeklere atanmış görevlerle açıklanmaktadır (García-González ve Piñeiro-Otero, 2011). Başarı beklentisi cinsiyete atfedilmiş değerlerle orantılı olarak belirlendiği için de kadınların kadın olmak ve dişilikle eşleştirilen iş tanımları ve sorumlulukları dışında sorumluluk alabilmesi için toplumsal cinsiyet tanımlarına göre erkeklerle eşleştirilen özelliklere sahip olması gerekmektedir. Standart bir kadının ise erkeklere ayrıımış alanlarda başarı göstermesi beklenmediği için bu çalışma alanlarında geride bırakıldığı görülmektedir.

\section{Araştırma}

\section{Araştırmanın Amacı, Önemi ve Sınırlılıkları}

Bu araştırmanın temel hedefi, kültürel üretimin bir parçası olarak reklam sektöründe çalışan kadınların iş yaşamında toplumsal cinsiyete bağlı konumlarını, koşullarını ve karşılaştıkları sorunları anlamaktır. Türkiye'de toplumsal cinsiyet ve reklam ilişkisi üzerine yapılmış son 10 yıldaki bazı çalışmalar incelendiğinde ${ }^{1}$; akademik literatürün genelde göstergebilim (Ügümü Aktaş; 2018), içerik analizi (Adalı Aydın; 2016) ve söylem analizi (Hülür ve Kalafat Çat; 2018) yöntemleri kullanılarak yapılan reklamlarda kadın temsilleri / stereotipleri ve toplumsal cinsiyet rolleri üzerine metin analizleri olduğu görülmektedir. Bu araştırmaların büyük çoğunluğunu basın (Oğuz, 2013) ve TV (Duman vd; 2014) reklamları oluşturmaktadır. Doğrudan kadınlar üzerine olmayan ancak çocuklara yönelik reklamlar ve toplumsal cinsiyet (Başfırıncı ve Altıntaş; 2019) üzerine yapılmış araştırmalar da bulunmaktadır. Ayrıca Kurultay (2019) tarafından sektör içinde reklamcıların başarısını gösterme anlamında bir ölçüt olarak görülen ödül törenlerinden Kristal Elma Yaratıcılık Festivali'nde sektördeki kadınların temsil oranları incelenmiştir.

Sektörel bazda Reklamverenler Derneği ve Reklamcılar Derneği'nin Birleşmiş Milletler kaynaklı "Unstereotype Alliance" (UN Women)'a katılımı (rvd. org.tr/a), bağlantılı Reklamverenler Derneği'nin 2017 yılında kurulan "Reklamda Toplumsal Cinsiyet Eşitliği Kurulu" ve sektörel eğitim projeleri (rvd.org.tr/b) ve Reklamverenler Derneği öncülüğünde gerçekleştirilen Effie ödüllü reklamlar üzerinden gerçekleştirilen "Reklamlarda Toplumsal Cinsiyet Eşitliği Karnesi" (rvd.

1 Tarama Dergipark, TR Dizin ve Google Akademik üzerinden gerçekleştirilmiştir. Belirtilen 10 yıllık dönem içerisindeki tüm çalışmaları kapsamamaktadır. 
org.tr/c) gibi son yıllarda artan çalışmaların da yine çoğunlukla reklam içeriği, kadın temsili ve söylemi ile sınırlı kaldığı görülmektedir. Bu genel literatür taraması sonrası Türkiye'de reklam ve toplumsal cinsiyete bağı sorunları üzerine reklam sektöründe çalışan kadınlar ile yapılmış bir araştırma tespit edilememiştir. Ancak tanımlayıcı / betimleyici olarak kabul edilmesi gereken bu nitel saha çalışmasının en önemli sınırlılıkları örneklemin çok dar olması ve niceliksel verilerin bulunmamasıdır. Bu sebeplerle araştırma sonuçlarından yola çıkarak herhangi bir genelleme yapılması mümkün değildir.

\section{Araştırma Soruları}

Araştırma soruları daha önce yapılmış başka nitel araştırmalardan faydalanılarak oluşturulmuştur (Alvesson, 1998: 21 katılımcı, Crewe ve Wang, 2018: 24 katılımcl, García-González ve Piñeiro-Otero, 2011: 15 katılımcı, Gregory, 2009: 45 katılımcı, Mallia, 2009: 18 katılımcı, McLeod vd., 2011: 47 katılımcı, Windels ve Mallia, 2015: 19 katılımcı). Araştırmaya konu olan ve veri analizinde de analiz çerçevelerini oluşturan sorular şu şekilde belirtilebilir:

S.1. Reklam ajanslarında toplumsal cinsiyete bağlı bir iş bölümü mevcut mudur?

S.2. Kadınlar mevcut departmanlar özelinde departmanlarını ve farklı departmanları, departman çalışanlarını ve çalışma ilişkilerini nasıl tanımlamaktadırlar?

S.3. Literatürde erkek egemen olarak tanımlanan kreatif departman kadınlar tarafından nasıl değerlendirilmektedir?

S.4. Kadınların reklam ajanslarında karşılaştıkları toplumsal cinsiyet sorunları ve eşitsizlikleri hakkında görüşleri nelerdir?

S.5. Reklamlarda toplumsal cinsiyet temsillerine ve feminizme yaklaşımları nasıldır?

\section{Araştırmanın Yöntemi}

Bu çalışma veri toplama tekniği ve verilerin analizi açısından nitel bir araştırmadır. Nitel araştırma insanların yaşam tarzlarını, öykülerini, davranışlarını, örgütsel yapıları ve toplumsal değişmeyi anlamaya dönük bilgi üretme süreçlerinden biri olarak kabul edilmektedir (Strauss ve Corbin, 1990 akt. Özdemir, 2010 s. 325). Nesnel bulgulara ulaşmayı hedefleyen nicel araştırma yöntemlerinin aksine derinlemesine görüşmelerle gerçekleştirilen bu nitel saha çalışmasında, konu hakkında daha fazla derinleşme ve tartışma imkanı sağlamak amaçlanmıştır.

\section{Araştırmanın Örneklem Seçimi}

Araştırma kapsamında sektör çalışanlarının niceliksel dağılımına dair ayrıntılı bir veriye ulaşılamamıştır. 2019 yılında Mediacat dergisi tarafından yapılan bir 
araştırmaya göre ${ }^{2}$ iletişim alanında kadın istihdamının görünümü şu şekildedir: 123 ajanstan gelen verilere göre; (kreatif reklam ajansları / 93 ajans, medya planlama ajansları / 15 ajans ve PR ajansları/12 ajans) toplam 4838 çalışandan 2467'si yani \%51'i kadındır. Bu kadınlar arasında toplam kadın nüfusu içerisinde \% 21'e denk gelen 528 kadın yönetici bulunurken, bu sayı toplam sektör nüfusunda \%11 ile sınırlı kalmaktadır. Bu toplam dahilinde 93 kreatif ajansta 3371 çalışandan \% 48 oranı ile 1624 kadın bulunmaktadır. 344 kadın yönetici toplam nüfusa göre \%10'a tekabül etmektedir. (https://mediacat.com/ajanslarin-kadin-erkek-yonetici-nufusu/)

Örneklemin belirlenmesinde mevcut literatürden faydalanılmıştır. Verilerin değerlendirilmesi sonrası kreatif tam hizmet reklam ajanslarında çalışan dağıllmının üç ana departmandan oluştuğu (Müşteri Illişkileri Departmanı, Kreatif Departman ve Stratejik Planlama Departmanı), bu üç departmanın Müşteri Iliş̧kileri ve Kreatif Departmanların yaklaşık eşit bir dağııımla reklam ajanslarının en fazla istihdam sağlanan bölümleri olduğu tespit edilmiştir. Edinilen enformel bir bilgi olarak reklam ajanslarının çoğunluğunun İstanbul'da bulunması sebebi ile saha bu şehirle sınırlı tutulmuştur.

Bu bağlamda amaçlı örnekleme yöntemi kullanılan çalışmada; çalışılan departman ve deneyim yılı stratejik değişkenler olarak kabul edilerek, 15 kadın çalışan ile derinlemesine görüşmeler gerçekleştirilmiştir. Yukarıda bahsedilen sebeplerle bu örneklem müşteri ilişkileri departmanından 6 , kreatif departmandan 6 ve stratejik planlama departmanından 3 kadın reklamcı olarak belirlenmiştir. Örneklem dahilinde müşteri ilişkileri departmanından 2 direktör, stratejik planlama departmanından 2 direktör ve kreatif departmandan 1 kreatif kökenli ajans yöneticisi pozisyonunda kadın bulunmaktadır. Tablo 1'de katılımcıların ayrıntılı bir listesi sunulmuştur. M harfi müşteri ilişkilerini, S harfi stratejik planlamayı, K harfi ise kreatif departman çalışanlarını temsil etmektedir. Deneyim yılı sayı olarak karışıklık yaratmaması ve örneklem seçimini kolaylaştırmak adına Tablo 2'de görüldüğü üzere belli yıl aralıkları ile sınırlandııımışıı. $0-5$ yıl arası deneyim A, 5-10 yıl arası deneyim B ve 10 yı üstü deneyim C kategorisi olarak sınıflandıııımıştır.

2 Mediacat dergisi ile Ocak 2020 ayında yapılan yazışmalar sonucunda kreatif reklam ajanslarında kreatif direktör, stratejik planlama direktörü, müşteri ilişkileri direktörü pozisyonları özelinde bir sayımın yapılmadığı belirtilmiştir. 
Tablo 1. Katılımcı Listesi

\begin{tabular}{|r|c|c|c|}
\hline No & Katılımcı & Departman & Deneyim $^{*}$ \\
\hline 1 & M-1 & Müşteri Illişkileri & A \\
\hline 2 & M-2 & Müşteri Ilişkileri & B \\
\hline 3 & M-3 & Müşteri Illişkileri & B \\
\hline 4 & M-4 & Müşteri liş̧kileri & C \\
\hline 5 & M-5 & Müşteri Illişkileri & C \\
\hline 6 & M-6 & Müşteri Iliş̧kileri & C \\
\hline 7 & S-1 & Stratejik Planlama & A \\
\hline 8 & S-2 & Stratejik Planlama & B \\
\hline 9 & S-3 & Stratejik Planlama & C \\
\hline 10 & K-1 & Kreatif & A \\
\hline 11 & K-2 & Kreatif & A \\
\hline 12 & K-3 & Kreatif & A \\
\hline 13 & K-4 & Kreatif & B \\
\hline 14 & K-5 & Kreatif & C \\
\hline 15 & K-6 & Kreatif & C \\
\hline
\end{tabular}

Tablo 2. Deneyim Yılı Kategorileri

\begin{tabular}{|c|c|}
\hline \multicolumn{2}{|c|}{ Deneyim* $^{*}$} \\
\hline $0-5$ & A \\
\hline $5-10$ & B \\
\hline $10+$ & C \\
\hline
\end{tabular}

\section{Veri Toplama Tekniği}

Araştırmada nitel bir veri toplama tekniği olarak yarı-yapılandırılmış derinlemesine görüşmeler yapılmıştır. Görüşmeler Eylül 2019 ve Ocak 2020 arasında yüz yüze ve yazarlar tarafından gerçekleştirilmiş olup, yaklaşık 60 ile 90 dakika arası sürmüştür. Saha çalışmasının yapıldığı tarih aralığı nedeniyle etik kurul izni gerekmemektedir.

\section{Verilerin Analizi}

Araştırma sonuçlarının değerlendirilmesinde verileri daha ayrıntılı ve sistemli ele alabilmek adına betimsel analizden yararlanılmıştır. Analiz süreci öncesi 
görüşmeler yazarlarca deşifre edilmiştir. Betimsel analize uygun bir şekilde elde edilen ham bulgular öncelikle yukarıdaki araştırma sorularına bağlı analiz çerçeveleri ile ilgili üst temalar altında derlenmiş, sonrasında ise bu saha özelinde ortaya çıkan kalıplar ve kalıp davranışlarla oluşturulan alt kategoriler yoluyla desteklenmiştir. Bu çerçeveler uyarınca görüşme yapılan kişilerden doğrudan alıntılarla sonuçlar ortaya konulmuş, yazarlar tarafından sorunsal kısmı ile bağlantılı ve araştırma sorularını aydınlatacak yorumlar yapılmıştır. Bu analiz adımları dahilinde nesnelliğe görece yaklaşmak adına her araştırmacı ayrı olarak tüm görüşmeleri incelemiş olup, araştırma yazım aşamasında ortak bir değerlendirme yapılmıştır.

\section{Araştırma Bulguları}

\section{Toplumsal Cinsiyete Dayalı İş Bölümü}

Reklamclık sektöründe toplumsal cinsiyetin bir yansıması iş bölümü ve bağlantılı departmanlar üzerinde görülmektedir. Cinsiyete bağı yapılan bu ayrıştırma, sektörde kadınların profesyonel olarak ilerlemesini önlemekte ve reklam sektöründe kadınların yaşadığı problemlerin temelini oluşturmaktadır. Tüm bulguların gösterdiği kadının doğa, erkeğin kültür ile ilişkilendirildiği "özcü" bir yaklaşımın doğallaşmış hali olduğudur. Bu durumun sadece reklam sektörü için geçerli olduğunu söylemenin yanlış olacağı, tüm toplumsallaşma süreçleri için geçerli bir sosyolojik verinin yansıması olduğu kabul edilmelidir.

\section{Müşteri İlişkileri ve Stratejik Planlama Departmanları}

Departmanlar arası cinsiyetçi iş bölümü, katılımcıların kendi departmanları ve farklı departman çalışanları için betimledikleri ile de açıkça görülmektedir. Katıımcıların bir kısmı bu ayrışmayı kadın ve erkeklerin sahip oldukları farklı yetenekler üzerinden açıklarken, temelde özellikle kreatif departmanda hemcinsleri arasında sosyalleşmenin erkek yönetici ve çalışanlar tarafından tercih edildiği özellikle müşteri ilişkileri ve stratejik planlama departmanları çalışanları tarafından kabul edilmektedir.

S1-A, "erkek kardeşliği"nin içinde "dışlanmamak" için kreatif departmanda çalışmak istemeyeceğini belirtmiştir. Ancak bu durumu "gelenek" olarak yorumlayan, "saygı duyan" katılımcılar da bulunmaktadır. Bir katılımcı, departmanlardaki cinsiyet dağıımının doğru ve haklı sebepleri olan bir dağılım olduğunu düşünen meslektaşlarıyla karşılaştığını ve eski bir düşünce olduğu düşünülse de hala yaygın olduğunu belirtmiştir. Diğer yandan katılımcılar sektörün diğer meslekler ile karşılaştırıldığında daha eşit bir kadın / erkek dağılımına sahip olduğunu düşünmektedir. Ancak yukarıda belirtildiği üzere bu eşitliğin yönetici pozisyonlarında karşılık bulmadığı görülmektedir.

Kadınların içselleştirdiği "doğal" olan kadına ait özellikler departman fark etmeksizin ya açık olarak ya da dolaylı olarak farkı nitelemelerle defalarca tekrar- 
lanmıştır. Kadınların komplike, olması, incelikli düşünebilmeleri, (değişen sıralamalarla) sol veya sağ beyinlerini kullanmaları, insanlar arasında daha iyi ve kolay iletişim kurabilmeleri, empati yeteneğinin daha yüksek olması ile bağlantılı daha anlayışlı ve yumuşak olmaları, tatı tatlı konuşan, temiz giyinen ve güzel görünen gibi çok farklı ama kabul edilmiş söylem ve nitelemeler ile ilişkilendirilmiştir. Bu durum yukarıda bahsedildiği üzere toplumsal cinsiyetin ve kodlarının içselleştirilmiş olduğunun açık bir örneğidir. Diğer yandan genel olarak erkekler daha basit ve dağınık düşünen, pozitif bir özellik olarak doğrudan ve düz varlıklar olan, idare edilmesi gereken, çabuk sinirlenen, argo kullanan vb. "doğal" kabul edilen eril özelliklerle nitelendirilmiştir. Özellikle kreatif departmanda çalışan kadınların müşteri ilişkilerinin dış görünümlerine ilişkin nitelemeleri de bu duruma bir örnektir: "çıtı pııı", "şıkır şıkır giyinen", "topuklu ayakkabıı", "hanım hanımcık", "makyajlar", "fönlü saçlar", "tatıış" ifadeleri kullanılmıştır.

M4-C, sosyalleşme kabiliyetleri sebebiyle "kadın ve gaylerin" müşteri ilişkileri departmanında çalışmayı tercih ettiğini, erkeklerin ise konuşmayı ve dert anlatmayı sevmediği için tercih etmediğini belirtmiştir. Benzer ifadeler kullanan bir başka katıımcı ise kadınların çok yönlü düşünebildiğini ve empati yeteneğinin daha çok olduğunu; ajansta çalışan bir kadın olarak sıkıntı yaşamadığını, aksine iletişim kurarken kadın olmanın yararını gördüğünü söylemiştir.

Stratejik planlama departmanı konusunda her ne kadar iki katılımcı erkek, bir katılımcı ise kadın çalışanların yoğunlukta olduğunu belirtse de çoğunluk açısından eşit bir dağılımın olduğunun düşünüldüğü söylenebilir. Görece tüm ajans çalışma ve ilişki pratiklerinden bağımsız olan strateji departmanı (S3- C) cinsiyet dağılımı ve stereotipleştirme konusunda da farklılaşmakta ve daha belirsiz hale gelmektedir:

"Stratejinin cinsiyeti yoktur. Öyle tam ifade edecek bir tanımlama bulamadım. Ama merakıı kişilerdir. Neredeyse "geek" (Türkçeye farklı veya argo bir tabirle inek olarak çevrilebilir.) diyebiliriz. (K2-A)

Ajans içi departmanlar arası ilişkiler ve pratikler incelendiğinde, planlama, fikirlerin ve kampanyaların sınırlarının çizilmesi ve müşterilerle ilişkilerin sağlanması görevini yerine getiren stratejik planlama ve müşteri ilişkileri departmanında çalışan katılımcılar, kreatif departman çalışanlarıyla iş sebebiyle yaşadıkları bazı sorunları ya da kendi sorumluluklarını anlatırken "kreatif departmanın idare edilmesi" ya da "gerginlik çıkmasının önlenmesi" gibi konulara özellikle değinmişlerdir. Bazı katılımcılar için bu müşteriden gelen bir isteğin kreatif ekibe onları "rahatsı etmeyecek şekilde iletilmesi" (M2-B), "kreatiflerin alanlarına girmediklerini göstermek" için çabalamak anlamına gelmektedir.

"(Yaratıcı brief verildiğinde) Bazı kişiler direkt, yani kreatif ekipteki kişiler işlerini elinden alıyormuşuz gibi hissedebiliyorlar. Çünkü ortada bir fikir var sonuçta ofansif davranan insanlar çıkıyor tabi arada (...) Zaten yaratııılar genelde fazla egosantrik insanlar olduğu için tabi ki de sorun çıkabiliyor o anlamda." (S1-A) 


\section{Kreatif Departman}

Sosyal ilişkiler ve ajans kültürüne uyum sağlamanın çok önemli sayıldığı sektörde, iş yapma pratiklerinin kurallara ve katı yöntemlere bağlı olmadığı kreatif departmanda, "işin doğası gereği", yaratıcı fikir bulabilme ve yaratıcı süreçlerin ilerletilebilmesi açısından daha rahat bir çalışma ortamı gerektiği belirtilmektedir. Yukarıda bahsedildiği üzere kreatif departman, literatürde "erkek soyunma odası" olarak adlandırılmıştır. Gregory (2009) erkek soyunma odasını "erkek gücü", "erkek kimliği", "rekabet", "erkek dayanışması" ve "ergen davranışları" ile ilişkilendirmiştir. Erkekler için güvenli bir alan olarak kabul edilen, rahatça sırlarını paylaşıp, cinsiyetçi ifadeler ve metaforlar kullanarak kadınları metalaştırarak sosyalleşebilecekleri bir alandır.

Bunun yanında, müşteri ilişkileri departmanı çalışanları tarafından erkeklerin departman içindeki hakimiyetlerini temsil eden bir durum da müşteri ilişkileri ve strateji departmanı çalışanlarının betimledikleri kreatif özellikleridir. Çoğunlukla kreatif departman çalışanı denildiğinde, katılımcılar müşteri temsilcisi için betimledikleri imajının aksine marjinal, farklı görünen ve rahat giyimli bir erkek profili çizmişlerdir:

“(...) böyle renkli, cıvıl cıvıl, farklı kıyafetler giyen, renkli çorapları olan; erkeksi, sakallı, gözlük takan, küpe takan vesaire genelde bu tip tipler." (M2-B)

Diğer yandan kreatif departmanda çalışan kadınlar açısından kreatifin genel betimlemesi az çok benzer özellikler gösterse de daha pozitif ve "farklıık" üzerine yoğunlaştığı görülmektedir. Bir tür "bilişsel uyumsuzluk" yaratmaması adına bu durumun saha bulguları ve literatür sonuçlarından yola çıkılarak, görece rasyonelleştirildiği söylenebilir. Kreatif kadınlar özellikle cinsiyet konusunda eşit bir dağııımın olduğunu düşünmektedir.:

“Kadın veya erkek olarak ayıramam. Çünkü eşit bir dağılım var bence (...) Kreatif departman çalışanları genelde de(y)işik tipler diyebilirim. (Güler). Öyle olmak için uğraştığından değil, ama zaten öyle olduğundan." (K3-A)

Erkeklerin arasındaki sosyal ilişki, ortak ilgi alanları ve sosyal etkinliklere uyum sağlayamayan özellikle yeni mezun kadın kreatif çalışanların ise ajanstan ayrılması ya da departman değiştirmesi rastlanılan bir durumdur.

“Ben ilk geldiğim sene, herkesin erkek, art direktörünün, yazarının, bir sürü insanın erkek olduğu, içlerinde bir tane kadın yazarın olduğu bir ekip vardı. (...) Kadın çalışan da yeni başlamıştı yani, bir senedir falan çalışıyordu. Öğrencilikten yeni de çıkmış. O mesela barınamadı, gözümüzün önünde gitmek zorunda kaldı ajanstan. Çünkü işte beraber, diğerleri playstation oynamaya gidiyoruz deyip, işi çözüp, ona haber vermemeler, bir şekilde dışarıda kalmak zorunda kaldığını hatırıyorum. Hatta bu laf dalaşlarında da detay hatırlamıyorum ama, cinsiyetçi şeyler olduğunu hatırlıyorum." (S2-B) 
Ancak üç farkıı departman çalışanı kadınlara bildikleri kreatif direktör kadınları söylemeleri istendiğinde sayıca bilinmediği, sayılan isim / ajansların da benzer olduğu görülmektedir. Ancak diğer katılımcılar tarafından da ortak olarak belirtilen bir bulgu olarak, uzun çalışma saatleri ve özellikle anne olan kadınların sektörü daha çok bırakması sebebiyle direktör sayısının azıı̆ının argümante edilmesidir:

“Kreatif direktör kadın... Evet var biliyorum. (İsmini hatırlıyor musunuz) Yani X miydi... Tam hatırlamıyorum ama var. (Neden daha az olabilir?) Bilemiyorum, tercih etmiyor olabilirler." (M6-C)

"Kadın kreatif direktör biliyorum. Temasta olduğum 2 tane var şu an. Ama onlar da çok eski. Benim jenerasyon." (S3-C)

"Kadın kreatif direktör üç tane biliyorum. Yani başka aklıma gelmiyor şu anda. Var tabi ki" (K2-A)

Departmanlar arası ilişkilerde kreatif departmanın "sancılı süreçlerden" geçerek (K5-C) ortaya koyduğu yaratıcı işlerin özellikle müşteri ilişkileri departmanı çalışanları tarafından müşteriden gelen revizyonlar doğrultusunda sürekli değiştirilmeye çalışılması sıklıkla "bir gerilime ve çatışmaya" (K6-C) yol açmaktadır. Ancak yukarıda geçen ve kadının doğal özellikleri kabul edilen "idare etme" ve "tatlıık" gibi yetenekleri bu çatışmaları aşmada çözüm olarak görülmektedir. Bu yeteneklerini kullanan müşteri temsilcileri "iyi müşteri temsilcisi" olarak adlandırılırken, bu yönetim gücüne sahip olmayanlar ve doğrudan müşterinin revizyon ve isteklerini aktaranlar "süzgeç" (S3-C) olarak kabul edilmektedir.

\section{Yeni Mezunlar}

Organizasyonlarda, bu araştırma dahilinde de iş yerlerinde, topluluğa yeni katılan kişi kendisine verilen iş tanımındaki görevlerin yanı sıra topluluğun kurallarını, normlarını ve topluluğa uygun kişilik ve davranış kalıplarını, ilgi alanlarını, esprileri, sohbet konularını, aktiviteleri de öğrenmektedir. Topluluğun mevcut üyeleri sahip oldukları tecrübe ve bilgiler sebebiyle yeni katılımcılar üzerinde güç sahibidir ve söz konusu öğrenme topluluğu diğer üyelerini izleyerek, onların rehberliğinde ve katılımla gerçekleşmektedir. Böylece yeni katılımcı topluluğa uygun yeni alışkanlık ve tutumlara sahip olmakta ve kişinin kimliğinde değişimler meydana gelmektedir (Salminen-Karlsson, 2006).

Görüşülen kadınlardan sektörde "yeni mezun" olarak anılanların karşılaştıkları çok benzer ve ortak sorunlar bulunmaktadır. Bu sorunların başında reklam sektöründe çok sık karşılaşılan "bitmeyen" ücretsiz stajyerlik süreleri gelmektedir. Diğer yandan işe başlama sonrası süreçte dahi asgari ücretin ödenmesi önemli bir sorun olarak görülmektedir. 
Kreatif departmanda işe girmeye çalışırken çok fazla şeyi "yuttuğunu" belirten K2-A, K3-A'nın da benzer söylemler ile desteklediği gençlik yani yaş farkı sebebiyle sorunlarla karşılaştığını söylemiştir:

"40 yaşında art'a gidip şunları değişecekmiş dediğimde, sen bir az dur bakalım, ne zaman adam oldun da revizyon veriyorsun dediği oldu."

M6-C de benzer şekilde sektöre ilk girdiğinde eski kreatifler tarafından çok fazla terslenmeye maruz kaldığını belirtmiştir. Yine S3-C, yeni mezun "müştem'in" (müşteri temsilcisi) çelik gibi sinirleri olması gerektiğini, yoksa bir yanda müşteri, diğer yanda kreatif "dayak yiyeceğini" dile getirmiştir.

Bazı kadınların şahit olduğu ortak sayılabilecek bir bulgu ise stajyer seçimi sürecidir. Özellikle kreatif departmanda erkekler arası konuşmalarda, örnek olarak "abi güzel mi", "zengin mi", "güzelse alalım" gibi söylemlerle ilerlendiği ve sosyal medya hesaplarının kimi zaman incelenerek bir karar verildiği belirtilmiştir.

\section{Kadın Yöneticiler}

Literatürde "Kraliçe Arı Sendromu" (Queenbee Syndrome) (Derks vd., 2011; Derks vd., 2016) olarak adlandırılan bir teoriden yola çıkılarak, özellikle yönetici kadınların "daha erkeksi" tavırlarla diğer kadın çalışanlara karşı erkeklerden daha sert ve dışlayıcı olmasının, reklam sektöründe de karşılaşılan bir durum olduğu söylenebilir. Belirtilmesi gereken bu sosyo-psikolojik tespitin doğrudan kadınların tercihleri ile ilgili değil ancak yine erkek egemen organizasyonlarda cinsiyet ayrımcılığının bir sonucu ve bir ayakta kalma stratejisi olduğudur. Sektörde ne çektiyse kadınlardan çektiğini ve iş değiştirdiğini dahi söyleyen K3-A'yı destekleyen bulgulara ulaşımıştır. Ortak noktalar olarak söz konusu sendromun özelliklerini barındıran bir "yönetici" profili karşımıza çıkmaktadır:

"Sektörde yükseldikçe erkekleşen çok kadın biliyorum. Özellikle yönetici pozisyonundaki kadınlar erkek gibi davranabiliyor. Bu diğer kadınları çıldırtıyor. Erkek yapsa aynı şeyleri idare edebiliyorlar. Erkekleşen kadından ben de hoşlanmıyorum açıkçası." (K4-B)

"Ben hamileyken erkekler saçma bir şekilde sanki sakatmışım gibi acayip ilgi gösteriyorlardı. (...) Ama hamile bir kadına ya da yeni çocuğu olan bir kadına en kötü davranan yine çocuk sahibi kadındır. Sanki biz de çocuk yaptık ama çalıştık. Sen de eşek gibi çalışacaksın." (K6-C)

Bu durumun yine doğallaşmış / doğallaştııımış kadın ve erkek özellikleri ile mantıklı hale getirildiği görülmektedir:

“Üstünüzle çok rekabet olur. Genelde kadın olduğu için bence. İki kadın birbiriyle zor anlaşır. Erkekler de olsa müşteri ilişkilerinde daha dengeli olur." (M2-B) 
“Erkek ve kadın daha rahat anlaşıyor. Yani kadın klasik ailede de olduğu gibi idare ediyor. Erkek daha doğrudan. Yani iki erkek arasında tartışma çıksa doğrudan kavga ederler, sonra kapanır mevzu. Kadınlar öyle değil" (K5-C)

\section{Annelik ve İş Yaşamı}

Uzun çalışma saatleri reklam sektörünün bilinen bir gerçeğidir. Haldankar'a (2017) göre, çalışanların iş ve hayat dengesini bozan bu sistemin ajanslar tarafından yaygın şekilde kullanılmasının sebebi uzun çalışma saatlerinin verimliliği ya da olumlu etkisi değil, diğer tüm ajansların da bu şekilde çalışmasıdır. Reklamclık sektörünün yoğun ve belirsiz çalışma şartları, yöneticilerin çalışanlardan beklentileri ve toplumun kadınlara yüklediği görevler göz önünde bulundurulduğunda, sektörde çalışan kadınların çocuk sahibi olması ve bunun kariyerlerine etkisi önemli bir konu haline gelmektedir. Toplumsal olarak kabul görmüş "Annelik Miti"nin temel bir açıklama olduğu söylenebilir (Crewe ve Wang, 2018). Diğer yandan Mallia (2009) da kadınlar açısından kişisel özelliklerin yanında en önemli ve belirleyici faktörün annelik olduğunu belirtmiştir. Kadınların kariyerlerinde ilerleyebilmek adına evlenmek ya da anne olmaktan vazgeçmeleri, çocuk sahibi olan kadınların ise mesai saatleri daha belirli işlere geçmeleri veya çalışmayı bırakmaları katıımcıların tanıdık oldukları senaryolardır. Bazı katıımcılara göre, reklamcılık sektöründe çalışan bir anne olmak, kadınların başarısını olumsuz etkileyen bir durumdur. S1-A'ya göre işe alım aşamasından itibaren anne olma ve anne olma intimali sektörde kadınların önüne engel olarak çıkabilmektedir:

"Yani tabi ki de her sektörde olduğu gibi 'bu evliyse birkaç sene sonra doğurur, işten ayrılır' onun gibi şeyler oluyor yani. O yüzden bence (işe) almadıkları da oluyor."

M5-C ise, toplumda kadının "annelik" rolü üzerinden tanımlanmasına değinmiş, kariyerlerinin gidişatını belirlediğini belirtmiştir. Katıımcıya göre, bu durum sektörde çalışan kadınların başarısını olumsuz etkilemektedir. Kreatif departmanda çalışan K1-A ise kadınların çocuk bakımı da dahil olmak üzere erkeklerden daha çok sorumluluk üstlendiğini, bu durum karşısında sektörde yükselebilmek için fedakarlık yapmaları gerektiğini vurgulamıştır. Bu noktada katıımcı sektörde çalışan bazı kadınların "pes ettiğini" ve fedakarlık yapmayı tercih etmediklerini belirtmektedir.

K1-A'in bu sözleri, sektörde özellikle erkekler tarafından normalleştirilmiş ve çalışanlardan temelde beklenen davranışların bir özetini vermektedir. Diğer yandan görüşülen kişilerden kreatif departmandan 2 kişi (K4-B, K5-C) annelik sonrası son 2 yıldır freelance çalışmakta olup, müşteri ilişkilerinden 1 kişi (M6-C) ise kurumsal tarafa yönelmiştir. 


\section{Reklam Ajanslarında Toplumsal Cinsiyet Sorunları}

Reklam sektörü yenilikçi, yaratıcı ve entelektüel çalışanların bir araya geldiği bir sektör olarak, cinsiyetçi tutum ve davranışların olmadığı bir sektör imajı yaratsa da erkek egemen bir sektördür (Ayhan, 2010). Katılımcıların bir kısmı sektördeki cinsiyetçiliğin hayatın herhangi bir alanından farklı olmadığını belirtirken, bir kısmı ise sektördeki erkeklerin cinsiyetçi olamayacak kadar eğitimli ve modern olduğunu savunmaktadır. Buna karşın, ikinci görüşü savunan katılımcılardan görüşmenin farklı kısımlarında kadınların sektörde bazı cinsiyetçi tavırlara maruz kaldığı belirtilmiştir.

Illk görüşe daha yakın duran M5-C, ajansın "rahat" ve "marjinal" davranışların normalleştiği ve cinsiyetçi söylem ve davranışların da bu kapsamda gerçekleştirildiğini söylese de, çalıştığı departman dahilinde kadınlar çoğunlukta olduğu için reklam sektörünün daha "şansıı" olduğunu belirtmiştir:

"Tabi ki kadın olarak çalışıyor olmanın verdiği birtakım zorluklar oluyor. Ama bizim sektör bir tık daha bence bununla ilgili şanslı. Çünkü kadınların ağırlıkta olduğu, marka tarafında, müşteri kısmında da ağırlıkta olduğu bir yer." (M5-C)

Özellikle kreatif departman çalışanı kadınların bu tür bir erkek egemen yapıyı tam olarak kabul etmedikleri söylenebilir. Bu duruma K1-A'nın henüz sektörde cinsiyetçi bir tavırla karşılaşmadığını, cinsiyeti yüzünden yetkinlikler konusunda bir şüphe yaşanmadığını belirtmesi örnek olarak verilebilir. Bunun dışında iş ortamındaki sohbetler sırasında günlük hayatta karşılaşılan toplumsal cinsiyet rolleriyle ilgili tartışmaların da yapıldığını belirtmiştir. Katılımcı, diğerlerine kıyasla, en az cinsiyetçiliğin reklam sektöründe olduğunu düşünmektedir. Diğer yandan karar verici pozisyonlarda erkeklerin bulunduğuna dair bir bakış açısı da bulunmaktadır:

“Müştemlerin toplantılarda karşılarına çıkanlar erkek. Yani evet birebirde çok fazla kadın müşteri tarafı gördüm. Ama kararı onlar vermiyor sonuçta. Markanın sahibi veriyor, ki o da erkek zaten. Biz sunuma gittiğimizde kreatif işler için son kararı işte markanın sahibi verir." (K4-B)

Sektörde erkeklerin kadın meslektaşlarına sıklıkla "mansplaining "3 yaptığı görülmüştür. Bir katıımcı sektörde özellikle buna çok maruz kaldığını ve şahit olduğunu belirtmiş, bu konuda hiçbir kadının tepki göstermediğini fakat kadın çaIışanlar arasında konuşulduğunu eklemiştir:

"Mesela sektörde eğer kadınsan, şeye de çok maruz kalıyorsun, diyelim ki aptalca bir şey denildiğini düşünüyor, hemen burada "Ah canım, sen anlamazsın

3 Mansplaining 2008 yılında bir blog yazısında ilk kez Rebecca Solnit'in kullanarak feminist literatüre kazandırdığı bir kavramdır. "Erkek" ve "açıklamak" anlamına gelen "man" ve "explaning" kelimelerinin birleştirilmesiyle oluşturulmuş kavram, özellikle beyaz erkeklerin, herhangi bir konuda daha yetkin ve bilgi sahibi oldukları kabulüyle kadınlara kişisel ve profesyonel olarak üstünlük taslamasıdır. (Joyce vd., 2021; Lutzky ve Lawson, 2019; Solnit, 2008) 
o işlerden" gibi mansplaining denir ya o çok oluyordu mesela. O beni rahatsız ediyordu. O senin beyninden dolayı değil de kadın olduğundan dolayı işten anlamadığın mesajını veriyor alttan alta." (S1-A)

Sektörde ve ajans içinde kadının rolü geleneksel anne-ara bulucu, iletişimi sağlama dışında açık bir şekilde "görsellik" olarak da belirlenmiştir. "Vitrinlik işler" önermesi dahilinde ele alınabilecek kadın çalışanların toplantılarda müşterileri memnun etmek için toplantıya götürülmeleri ve makyaj yaparak daha şık görünmeleri, toplumsal cinsiyet kıstaslarına uymalarının beklendiği bazı katılımcıların maruz kaldığı cinsiyetçi davranışlardandır:

"Benim hiç ilgim olmayan toplantılara, sırf orada sevimli görünmek için götürüldüm mesela. Yani aslında hiç işin içine girmeyeceğim durumlarda... Bence sırf kadın olduğum için ve o erkek ortamını yumuşatmak için, orada bir ikon olarak kullanılı̆ı̆m durumları hissettim. (...) Yani sırf hoş diye bir kadının toplantıya götürüldüğ̈ birkaç durumla daha karşılaştım. (M1-A)

Reklamlarda kullanılan eril dilin yanında, ajans içinde kullanılan dil ve sohbet konuları, toplantı sırasında tercih edilen ifadeler de reklam ajansı içerisindeki eril hakimiyeti gözler önüne sermektedir. Padavic'e (1991) göre erkek egemen olan işyerinde erkekler arasındaki bağ kurma yollarından biri cinsellik üzerine sohbetlerdir ve kadınların işyerine gelişi bu içerik ve ifadeleri zararsız dayanışma sağlayıCı bir sosyalleşme aracı olmaktan çıkarmaktadır. Sektördeki eril hakimiyetten gelen güç, erkeklerin ajans içi toplantılarda ya da sosyal ilişkilerde kendi aralarındaki ifade ve davranışları aynı rahatlık ve özgüvenle sürdürmelerini sağlamaktadır:

"Müşteriye gidiyoruz mesela, ajans içinde ajansın bir çalışanı diğerine bunu yapıyor. Ya da işte "ay bugün ne yapmışsın böyle, kendine biraz dikkat et. Şu bakımsızlık ne?". Bunların hepsi şaka kisvesi altında yapılıyor ve "canım arkadaşız zaten, takılamayacak mıyız?" deniyor." (S2-B)

Yaratıcı gücün, bu ortamdaki hegemonik erkekliğe bağlandığı (Gregory, 2009) çalışma alanında kadınların, ortama uyum sağlama ve bu dili ve ifadeleri kanıksayarak ve kullanarak departman içinde kabul görme mücadelesi verdiği de görülmektedir. Reklam kariyerine kreatif departmanda başlayan M3-B'nin kendi kreatif departman deneyiminde söyledikleri bu uyum sağlama pratiklerinin önemine örnek olarak verilebilir:

"Illk X'e girdiğimde kadın sayısı daha azdı kreatifte. $Y$ var bizim direktör. Herkes Y Baba diyor. Ben de Y'ye Y Baba dedim. Herkes deli gibi dalga geçti. Meğerse sadece erkekler baba diyormuş. Suçlu hissetmiştim. Kızlar Y diyormuş. (...) Yıllar geçti üzerinden başka bir yazarın kreatif direktöre abi dediğini duydum. Benim o kadar hoşuma gitti ki. Kendi içimde dert olmuş. Oh be kız yıkmış bunu dedim. Ona da söyledim aşmışsın bunu diye." 
Sektördeki ve ajans içindeki erkek dayanışması bazı katıımcılar tarafından eleştirilirken bazı katılımcılar ise bunun doğal olduğunu düşünmektedir. M4-C'ye göre erkeklerin sadece cinsiyetlerinden dolayı daha çok ortak yönü olması, ekiplerini erkeklerden oluşturması, erkeklerle birlikte çalışmak istemeleri normaldir ve verimliliği artırdığı sürece sorun teşkil etmemektedir.

Bunların yanında, dikkat çeken bir unsur yukarıda verilen bir örnekle desteklendiği üzere reklam ajanslarındaki cinsiyetçi ortamın, eril dil ve davranışların ajans ortamının "normali" olarak kabul edilmesi ve katılımcıların bunlara uyum sağlama, kanıksama ya da sessiz kalma davranışlarını benimsemiş olmasıdır. Bir katılımcı bu durumu ajansın doğal ortamı olarak tanımlamış ve artık tamamen normalleştiğini belirtmiştir. Fakat katılımcıya göre bu durum cinsiyetle alakalı değildir ve kadınların "istemedikleri hiçbir durum içinde kalmadığını" düşünmektedir. Ancak getirilen açıklama da tüm araştırmaya yansıyan eril ortamın içselleştirilmesinin bir sonucu olarak da kabul edilebilir:

"Ajans ortamı normal bir iş yeri gibi değil. İçeride bir sürü deli geziyor gibi bir ortam var. Yani hiçbir şey normal bir iş yerinde olması gerektiği gibi değil. Her şey rahat (...) Bu ortamda da anormalliklere de çok alışık olman gerekiyor bir taraftan. Atıyorum, küfür kullanmayan bir insansındır ama oradaki ajans başkanı çok küfrediyordur. (...) Yaşadığım bir örnek beni çok şaşırtmıştı. Ajansta ajans başkanının doğum günü, ajanstakiler ajans başkanına pasta yaptırıyor. Pasta meme şeklinde. Yani benim için şok. Hediye alıyorlar, p*pilerin olduğu kravat falan. Bir gariplik var. Illişkilerde de var bu arada (...) kadın erkek olmakla da alakası yok çünkü buradaki kadınların hiç birisi böyle ezilen büzülen, başına gelen bir olayla baş edemeyecek falan da değil." (M5-C)

Ajans içi cinsiyetçi kültürün normalleştirilmesine bir başka örnek, kendini "eski jenerasyon" olarak tanımlayan S3-C'nin söyledikleridir:

“Eskiden her sene yapılan ajansın açılış partisinde en'ler oylaması yapılırdı. İşte en güzel kız, en güzel p*polu kız, en güzel göğüslü kız gibi kategoriler olurdu. Hah ha ha (sesini kalınlaştırarak) hepimiz gülerdik. (...) Ama dünya değişiyor. Bunu bir Z kuşağına söylesen inanamaz. Onlar ne gerekiyorsa onu yapacaktır."

\section{Taciz ve Flört Arasındaki İnce Çizgi}

Bu bölümde katılımcıların sektörde yaşadıkları/şahit oldukları/duydukları taciz ve taciz olarak değerlendirdikleri / değerlendirmedikleri olaylar ve bunlara verilen/verilmeyen tepkiler incelenecektir. Sektördeki eğitim seviyesi ve kadınların toplumdaki görece üst pozisyonlarına rağmen gerek sektörün yapısı, gerekse tüm toplumu ilgilendiren cinsiyetçi ortam kadınların taciz gibi olumsuz durumlarla karşılaştığını göstermektedir. İlk olarak belirtilmesi gereken kişisel olarak yaşanılan, şahit olunan ya da başkasından duyulan bu tür olayların çoğunlukla genç kadınlar tarafından yaşanıldığıdır. Ancak katıımcılar tarafından belirtilen, taciz ve 
benzeri olaylarda yukarıda geçen bulgularla beraber düşünüldüğünde temelde neyin flört neyin taciz olduğu konusunda ortak bir fikir olmadığı görülmektedir. Bir katılımcı tarafından flörtün "sektörün üst başlığı" olduğunun belirtilmesi bu karışıklığı destekler nitelikte kabul edilebilir:

"Ajans ortamı sonuçta. Yani çocuklar bütün günlerini beraber geçiriyor. Kiminle flört edecekler." (S3-C)

"İlk başladığım ajans çok alkol alınan bir ortamdı, bir art direktör takmıştı bana. Yani her içildiğinde, sen nerede oturuyordun, nerede yaşıyordun, seni eve bırakayım mı? (flört olarak alabilir miyiz?) Birisi size bunu 30 kere soruyorsa düzenli, bu tacizdir bence. (...) Ama gençler arasında özellikle flörtleşme ve çıkma çok normal tabi ki" (K2-A).

Bunun yanında, ajans çalışanları arasındaki gayrı resmi ortam, gençlik ve deneyimsizlik, üstlerle abi-kardeş ilişkisi, çalışma şartları sebebiyle kurulan samimiyet ve "arkadaş" olma, ajansların alkollü ortamlar olması gibi durumlar psikolojik bariyer olarak kadınların önünde durmaktadır:

“Çok alkol alınılan ortamlar ajanslar. Dışarıdan çok eğlenceli görülebilir. Ama tam bir pejmürdelik. Direktörler çok rahat müştem kızlara sarkıntılık edebiliyor. Kreatif direktörümüz vardı. Çok meşhur biri. Alkol problemi de vardı. Yılbaşı kutlamasında benimle sohbet etmeye çalıştı. Defalarca ne yapıyorsun, hayatın nasıl soruları. Daha fazla yaklaşıp dans etmeye çalışmalar. Başkalarına da yapardı. 25 yaşındaydım o zaman. Tabi ki hepsi genç müştem jr. (...) (M6-C)

Buna karşın, bir katılımcıya göre, her ne kadar tacize uğrayan çalışanlar üstlerine ya da resmi mecralara şikayette bulunmasa/bulunmaktan çekinse de, yaşananların kadınlar arasında anlatılarak duyurulması bir koruma mekanizması yaratmaktadır:

"Bilmem ne ajansında bilmem kim işte taciz ediyormuş o yüzden işten ayrılmış arkadaşımı diye duydum. Sektörde öyle pislik, belli bir yere gelmiş statü sahibi, pis erkek tacizciliği var (...) (İşten ayrılan) Kadın oluyor, mağdur oluyor. Hiç daha tersini görmedim. Ama mesela belli başı isimler var, sektörde adı yayılmış. Şanı yürümüş (...). Kadından kadına gidiyor bunlar. Özellikle şu var bizim sektörde, bir yere başvuracaksın ya da oraya görüşmeye gideceksin, daha önce orada çalışmış biri mutlaka bulunur. (S2-B)

Yaşanan olaylar sonrası şikayet ya da herhangi bir yaptırım uygulandığını duymadığını söyleyen bazı katılımcılar, genellikle olayın üstünün kapatılığını belirtmişlerdir. Bir katııımcıya göre, öğrenilmiş çaresizlik ve sektör içi organizasyonun yarattığı tepkisizlik sebebiyle, kadınlar bu konuları aralarında konuşmasına rağmen tepki verme konusunda çekinceleri bulunmaktadır. Erkek dayanışması ve bu durumun sektördeki erkeklere verdiği güç, popüler olan kişilere karşı destek 
bulamama korkusu kadınların sektör içinde tacize ve cinsiyetçiliğe karşı örgütlenmesine engel olmaktadır. Bu tepkisizliğin bazı sebepleri olarak iK ve ilgili başka bir departmanın bulunmaması, yönetici pozisyonunda yine erkeklerin bulunması, ajans için çok önemli olan bir çalışanın kaybedilmek istenmeyeceği, kadınların kendi işlerini korumak için "politik" davranmaları gerekliliği, uzun saatler çalışılan iş arkadaşlarına karşı hissedilen vefa ve sorumluluk duyguları ve özellikle yönetici pozisyonunda çalışan kadınların da -"kraliçe arı sendromu" dahilinde anlaşılabilecek- erkeği savunacağı gibi katıımcılar tarafından belirtilen bazı argümanlar gösterilebilir:

“(...) Iletmedim bir yere. Bu standart bir şey zaten. Herkes kendi arasında konuşur. Kreatif direktörü kaybetmek istemez yönetici. Geçiştirilir kesinlikle. Zaten kimin eli kimin cebinde belli olmayan bir ortam var. (...) Sizi işten bile çıkarabilirler. Müştem onları yutup yutup devam eder. Gururlu gururlu davranamazsınız." (M6-C)

Katılımcılardan bazıları aynı zamanda şikayet sonucunda sektörden dışlanma korkusu yaşandığını da düşünmektedir. Bunun yanında kullanılan dil sektör içinde normalleştiği için yukarıda bahsedildiği üzere karşı tarafın "şaka yaptığını" söyleyerek kendisini savunacağı belirtilmiştir. Bu noktada, özellikle şaka/iltifat, flört ve tacizin birbirinden ayırt edilemediği durumlarda geçici çözümlerle karşı tarafı "şakayla karışık uyararak" durumdan kurtulmaya çalıştığını belirten bir katılımcı, iş yerinde cinsel taciz konusunda eğitim verilmesinin faydalı olacağını düşündüğünü fakat bu konuda bir girişimde bulunmadığını söylemiştir.

Bir başka katılımcı ise (M5-C) sektörde "taciz benzeri" olayların oldukça normalleştiğini ve aslında tacize uğrayan kadınların da ses çıkaramayacak ya da haklarını savunamayacak durumda olmadıklarını düşündügünü belirtmiştir. Sektördeki ilk yılarında yaşadığı bir olay sonucu kendisini korumayı öğrendiğini ve reklam sektöründe istemeyen ve kendini koruyan hiçbir kadının kendisini "bu tarz" durumların içinde bulmayacağını düşündüğünü söylemiştir.

Tüm bunların karşısında 12 katılımcı yaşadığı / şahit olduğu / duyduğu taciz ve benzeri olayların olduğunu belirtirken, 3 katılımcının sektörde kesinlikle böyle bir durumla karşılaşmadığını ve "kadın olarak" hiçbir zorluk yaşamadığını dile getirmesi anlamlı bir bulgudur.

\section{Toplumsal Cinsiyet Reklamlar ve Feminizm}

Katılımcıların genel olarak toplumsal cinsiyet konusundaki düşünceleri Türkiye toplumu içerisinde özellikle yoğun olarak gündemde olan kadının maruz kaldığı şiddet, ayrımcılık konularına odaklanmaktadır. Öte yandan, katıımcılara göre toplumsal cinsiyet kalıpları, toplumun her kesiminden kadın için eşitsiz, kısıtlayıcı ve kırılması gereken kuralları ve kabulleri ifade etmektedir. Katılımcıların konu hakkında düşündükleri, sorguladıkları ve toplumsal cinsiyetle ilişkili problemleri 
benimseyerek günlük hayatları içinde cinsiyetçi söylem ve davranışlarla mücadele ettikleri söylenebilir. Buna karşın ajanstaki cinsiyetçilik özellikle kreatif katılımcılar için ikircikli bir noktadır. Öyle ki, bazı katıımcılar toplumsal cinsiyet kavramını "kadın cinayetleri" ve "olmayan cinsiyet eşitliği" ile anarken, ajans ortamına cinsiyetçi toplumsal kültürün yansıdığını belirtmesine rağmen, yukarıda da bahsedildiği üzere ajans çalışanı herkesin toplumsal cinsiyet eşitliğini de savunacağını dile getirmiştir:

"Kreatiften arkadaşların hepsi cinsiyet eşitliğini savunur. Bu konular açıldığında bazen bir kadından daha ateşli olabiliyorlar." (K3-A)

"Reklam sektöründe, ajanslarda bu konular aşıldı bence." (K5-C)

Bu bağlamda ajans ve sektör içerisinde cinsiyetçi bir tutum olmadığını düşünen katılımcılar genel olarak kendi çevrelerindeki erkeklerin de kadın-erkek eşitliğine inandığını belirtmektedir. Bu katıımcılar, aynı zamanda sektör içinde bazı alanların erkeklere ayırımış olmasını ve sektör içindeki erkeklerin ayrıcalıklarını cinsiyetçilik olarak değerlendirmemektedir. Genel olarak toplumsal cinsiyet kavramı sorulduğunda M4-C, kadın-erkek hukuk önünde eşit olduğu sürece konu hakkında tartışımasını "demode" bulduğunu belirtmiştir. Sadece 2 katılımcının toplumsal cinsiyet konusuna daha mesafeli olduğu görülürken, diğer katılımcıların toplumsal cinsiyet konusunda dahil olunan sosyoekonomik statü ile belirtilmesi beklenen genel kabul edilmiş ana başıklara hakim olduğu söylenebilir. Toplumsal cinsiyet konusunda sadece M3-B, LGBTi+ bireyleri de dahil etmiştir.

Reklamlarda toplumsal cinsiyet temsili, birçok açıdan katılımcıların benzer fikirler beyan ettiği bir konu olmuştur. Öncelikle çoğu katılımcı yaygın temsillerden rahatsız olduğunu belirtmiştir. Katılımcılar, kadınları genel olarak domestik taraflarıyla ön plana çıkaran bu temsillerin hem kendilerini hem de reklamcıların toplumsal cinsiyete ilişkin düşüncelerini yansıtmadığını düşünmektedir. Katılımcılarının neredeyse hepsinin belirttiği ortak görüş, toplumun zihnindeki kadın algısı ve rolü ne ise, reklamlardaki stereotiplerin de buna bakarak oluşturulduğu yönündedir. Bu tür derinlemesine reklam yorumlarının ve bu yönde sahip olunan bilinçliliğin, işin doğal bir sonucu olarak katılımcıların yüksek reklam okuryazarlığı seviyeleri gösterilebilir.

Katıımcıların çoğu kendilerine hatırladıkları cinsiyetçi bir reklam olup olmadığı sorulduğunda genel olarak kadınların anne ve cinsel nesne olarak temsil edildiği reklamlardan örnekler vermiş̧ir. Geçmişte yaygın söylem, kadının ev içi görevleri ve toplumsal cinsiyet rolleriyle sınırlı iken bu söylemlere zamanla kadınların bedenleri ve günümüz postfeminist söylemleriyle feminizmin metalaştııılması eklenmiştir (Banet-Weiser ve Portwood-Stacer, 2017; Goldman, 1992). Bütün katılımcılar güçlü kadın temsillerini ön plana çıkaran (empowering women) reklamların samimi olmadığını ve arka planda somut bir fayda sağlamadan "göstermelik" (K3-A) ve "ticari kaygılarla normal olarak kullanılan bir strateji" (S3-C) tasarladığını 
belirtmiştir. Bu tarz reklamların bir akım haline geldiği ve böylece söylemlerin içinin boşaltılığını belirten katıımcıların çoğunlukta olduğu kabul edilerek, K2-A bunun iyi bir başlangıç olduğu fikrini savunmuştur. Buna karşın, bazı katılımcılar kurumsal sosyal sorumluluk kapsamında gerçekleştirilen projelerin daha gerçekçi olduğunu düşünmektedir. İki katılımcı, "empowering women" söylemlerinin kendilerini rahatsız ettiğini belirtmiştir. Toplumsal cinsiyet olgusuna farklı bakış açısına sahip katıımcılardan M4-C bu söylemleri feminizm gibi demode bulmaktadır, M5-C ise "kadınlar her şeyi yapabilir" temalı kampanyaların toplumda gerçek bir karşılığı olmadığını, mevcut yapıya gerçek bir çözüm sunmadığını belirtmiştir. Benzer bir bakış açısıyla M2-B de şehirli bir kadın olarak reklamlarda öne çıkarılan eylemleri zaten yapabildiğini ve bu söylemlerin de yapamayan kadınlara bir fayda sağlamadığını düşünmektedir. S2-B ise ev işi, çocuk bakımı gibi kadına yüklenmiş rolleri erkeklerin de benimsediğini gösteren reklamların aslında erkekleri değil kadınları hedeflediğini, bu noktada amaçlanan şeyin farklılık yaratmak değil, bunu isteyen kadınları ürünü almaya teşvik etmek olduğunu savunmaktadır.

Katılımcıların feminizm ve feminist olmakla ilgili düşünceleri genel olarak iki farklı şekilde gruplanmaktadır. Bazı katıımcılar feminist olduklarını, her kadının feminist olması gerektiğini söylerken, iki katılımcı ise feminist ifadelerin fazla "kızgınlık" ve "kırgınlık" barındırdığını belirtmiştir. Buna karşın genel bir açıklama ile feminizmin tam olarak ne olduğu ya da kimin feminist olabileceği gibi konularda net bir düşünce bulunmadığı; hatta bazı örnek ifadeler olarak feminist olmak için "evli olmamak" gerektiği, feministlerin "kafatasçı" ve "marjinal" olduklarının belirtildiği söylenebilir. Bu bağlamda feminist olduğunu belirten kadınlar için de sınırlar yaklaşık bu kavramlarla belirgin hale gelmektedir:

"Evet feministim. Ama çok aşırı değil. Nasıl desem yıkıcı ve marjinal olanlardan ayrı tutuyorum kendimi." (K5-C)

Öte yandan, M2-B aktivist bir eylemde bulunmadığını ancak kendini feminist olarak tanımladığını ve günlük hayatı içinde karşılaştığı cinsiyetçi davranış ve sözlere karşı çıktığını, tartışmaktan çekinmediğini belirtmiştir. Feminist olduğunu ifade eden bir başka katıımcı ise işe alımlarda, eğitim, tecrübe gibi tüm unsurların eşit olduğu adaylarda kadınlara pozitif ayrımcılık yaptığını fakat bunun ahlaki açıdan nerede durduğunu kestiremediğini dile getirmiştir.

Sonuç olarak feminizmin gerek toplum genelinde, gerekse reklam sektörü özelinde üzerinde uzlaşılan bir kavram olmadığı görülmektedir. Medya aracılığı ile yaratılan "feminazi" ve "marjinal" kadınlar temsillerinin bu konuda önemli bir yanılsama yaratıtığı ve yanıltma aracı olduğu görülmektedir. Her ne kadar çok farklı feminist kuram, kuramcı veya fraksiyondan bahsedebilsek de, reklam sektöründeki kadınlar açısından liberal feminizmin baskın olarak söylemlere yansıdığı görülmektedir. 


\section{Sonuç}

İstanbul'da faaliyet gösteren kreatif reklam ajanslarından farklı departmanlarda çalışan ve farklı deneyim yılına sahip 15 kadın reklamcı ile derinlemesine görüşmelerle gerçekleştirilen bu araştırmada, yabancı literatürle örtüşen sonuçlara ulaşılmıştır. Her ne kadar Türkiye ve toplumsal yapı özelinde, özellikle toplumsal cinsiyet olgusuna bakış konusunda farklılıklar ortaya çıksa da, reklam sektörünün uluslararası yapısı ve küresel kültürün ajans çalışanlarının sosyoekonomik statü ve yaşam tarzları ile de bağlantıı içselleştirilmiş olması, bu durumun çok genel bir açıklaması olarak kabul edilebilir. Araştırmanın en önemli sonucunun sorunsal kısmında da belirtildiği üzere toplumsal cinsiyetin öncelikle toplumsallaşma süreçlerinde, sonrasında ise bu saha özelinde de iş yaşamında öğrenilen, içselleştirilen ve doğallaştıılan bir inşa olduğudur (Padavic, 1991; Holmes, 2007).

Araştırma soruları üzerinden yapılabilecek bir değerlendirmede, kadınların reklam sektörünü yoğun ve yorucu bir alan olarak gördükleri belirtilebilir. Ajanslarda açık bir şekilde bir alan ayrımcılığının bulunduğu görülmektedir. Neredeyse tamamını kadınların oluşturduğu müşteri ilişkileri departmanı buna bir örnektir. Literatürde karşımıza çıkan erkek egemen (Gregory, 2009; Kuc, 2017) kreatif departmanların, departman dışı katıııcılarca benzer şekilde tanımlandığı belirtilmelidir. Ancak kreatif departmanın müşteri ilişkileri gözündeki eril yapısına rağmen, kreatiflerin çoğunluğu tarafından belirtilen eşit cinsiyet dağılımı ve eşitlik vb. bulgular aslında yukarıda bahsedildiği üzere bir tür bilişsel uyumsuzluk çözücü açıklamalar olarak kabul edilebilir. Katıımcıların söyledikleri arasındaki bazı tutarsızlıklar da bu durumun bir yansımasıdır. Bu bağlamda kadınların bir tür hipermetropi geliştirdiği, uzak / ajansdışı olan başlıklarda farkındalıklarının yüksek olduğu ancak yakın / ajansiçi açısından bulanık bazı alanlar bulunduğu söylenebilir.

Kadınların toplumsal cinsiyete bağlı karşılaştığı sorunların; annelik sebebi ile işten ayrılma veya sektör değiştirme (Crewe ve Wang, 2018), sektörde yükselme konusunda karşılaşılan güçlükler ve dikey ayrımcılık (Mallia, 2009) ve kültürel olarak belirlenmiş kadın ve kadınlık üzerine özelliklerle açıklanabilecek (García-González ve Piñeiro-Otero, 2011) cinsiyet ayrımcılıkları olduğu görülmektedir. Diğer yandan erkeklere has bir özellik olarak belirtilen ve kullanılan cinsiyetçi bir jargonun dahil olduğu "erkek hemcins toplumsallaşmasının" (Gregory, 2009), alan ayrımcıı̆ı̆ı sebebi ile aslında bir tür "kadın hemcins toplumsallaşmasına" da yol açtığı görülmektedir.

Sektör içi taciz ve bağlantılı / bağlantısız mobbing vakalarının yukarıda bahsedilen sebepler doğrultusunda çözümsüz kaldığı belirtilebilir. Bu konuda özellikle sektörle ilgili oluşumlara önemli bir görev düşmektedir. Ajans çalışanlarının taciz ve mobbing konusunda eğitilmesi, ajans yöneticilerinin ve takım/ departman liderlerinin önceliklerinin bu yönde belirlenmesi önem arz etmektedir. Reklam sektörünün sık çalışan / ajans değiştirilen ve bağlantıı sirkülasyonun yüksek olduğu yapısının, kurumsal hafızayı da zayıflattığı görülmektedir. Bu bağlamda ajans ve 
tüm paydaşlarla yazılacak etik kodlar bir başlangıç noktası olarak kabul edilebilir. Diğer yandan "herkesin herkesi tanıdığı" bir çalışma alanında ilgili dernek ve vakıflarca anonim iletişim kanallarının açılmasının caydırıı bir mekanizma olabileceği söylenebilir.

Kadınların sektör içi yaşadığı yapısal ve kişisel sorunlar, tüm topluma hakim olan eril yapının bir yansıması ve sonucudur. Beyaz yakalı olarak kabul edilebilecek katılımcıların aslında bu tür ayrımcıııkları iş yaşamında da deneyimleyerek öğrendiği görülmektedir (Salminen-Karlsson, 2006). Kurumsal ve organizasyonel bir sistemi bulunan herhangi bir yapıya dahil olmak, deneyim dışı kalan mevcut toplumsal cinsiyet eşitsizliklerinin içselleştirilmesine ve yeniden üretilmesine (West ve Zimmerman, 1987) yol açmaktadır.

Gelecek araştırmalar açısından niteliksel araştırmalar olarak örneklemin genişletilmesi, erkek reklamcıların örnekleme dahil edilmesi, reklamveren tarafı ile de görüşülmesi önerilmektedir. Diğer yandan tüm sektörü içerecek bir örnekIem tasarımı ile yapılacak niceliksel bir araştırma daha nesnel bilgilere ulaşılmasını sağlayacaktır.

Not: Bu çalışmanın alan çalışması Eylül 2019 yılında başlamış ve Ocak 2020'de bitmiştir. Tarihler nedeniyle "Etik kurul onayı" gerekliliği yoktur.

\section{Kaynakça}

Acker, J. (1990). Hierarchies, Jobs, Bodies: A Theory of Gendered Organizations. Gender and Society. 4(2). Erişim 28 Eylül 2020, http://www.jstor.org/stable/189609

Adalı Aydın, G. (2016). Popüler Kültür ve Reklam İlişkisi: Basılı Reklamlarda 14 Şubat Sevgililer Günü, Global Media Journal. 6/12. Erişim 23 Mayıs 2021, https://globalmediajournaltr.yeditepe.edu.tr/sites/default/files/G\%c3\%bclten \%20 ADALI\%20AYDIN_0.pdf

Aile ve Sosyal Politikalar Bakanlığı. (2018). Kadının Güçlenmesi Strateji Belgesi ve Eylem Planı 2018 - 2023. Ankara. Erişim 23 Mayıs 2021, https://ailevecalisma.gov.tr/media/6318/kad\%C4\%B1n\%C4\%B1n-gue\% C3\%A7lenmesi-eylem-plan\%C4\%B1-2018-2023-1.docx

Alvesson, M. (1998). Gender Relations and Identity at Work, A Case Studies of Masculinities and Feminititiesin in an Advertising Agency, Human Relations. 51 (8). Erişim 20 Eylül 2020, https://journals.sagepub.com/ doi/10.1177/001872679805100801

Arnberg, K. ve Svanlund, J. (2017). Mad women: gendered divisions in the Swedish advertising industry, 1930-2012, Business History, 59 (2). Erişim 17 Kasım 2019, https://ideas.repec.org/a/taf/bushst/v59y2017i2p268-291.html 
Ayhan, N.P. (2010). Sex structure of occupations in the advertising industry: Where are the female ad practitioners?. Observatorio Journal. vol.4 - no. 3. Erişim 28 Eylül 2020, http://obs.obercom.pt/index.php/obs/article/download/416/378

Banet-Weiser, S. ve Portwood-Stacer, L. (2017). The Traffic in Feminism: An Introduction to The Commentary and Criticism on Popular Feminism. Feminist Media Studies. 17(5). Erişim 12 Nisan 2019, https://www.tandfonline.com/doi/ abs/10.1080/14680777.2017.1350517?journalCode=rfms20

Başfıııncı, Ç. ve Altıntaş, M. (2019). Toplumsal Cinsiyetin Çocuk Reklâmları Aracıığıyla İnşası: Türk Televizyonlarındaki Çocuk Reklâmlarına Yönelik Bir İçerik Analizi. Istanbul Business Research, 47(2). Erişim 23 Mayıs 2021, https://dergipark. org.tr/tr/pub/ibr/issue/44184/550568

Butler, J. (2014). Cinsiyet Belası-Feminizm ve Kültürün Altüst Edilmesi. (Başak Ertür, Çev.). İstanbul: Metis Yayınları.

Büyükkayacı Duman, Y., Yılmazel, A. ve Akbulut Başcı, A. (2014). Kültürel Değişimin Türk Televizyon Reklamlarindaki Kadin İmajina Etkisi. Hitit Üniversitesi Sosyal Bilimler Enstitüsü Dergisi, 7 (1), 60-69. Erişim 23 Mayıs 2020, https:// dergipark.org.tr/tr/pub/hititsosbil/issue/7716/101026

Crewe, L., ve Wang, A, (2018). Gender inequalities in the city of London advertsing industry, Environnement and Planning: Economy and Space, 50 (3), 671 - 688. Erişim 23 Eylül 2020, https://journals.sagepub.com/doi/abs/10.1177/0308518X17749731

Derks, B., Ellemers N., Van Laar C., ve de Groot, K. (2011). Do Sexist Organizational Cultures Create the Queen Bee, British Journal of Social Psychology, 50 (3), 519 - 535, Erişim 21 Eylül 2020, https://www.semanticscholar.org/paper/ Do-sexist-organizational-cultures-create-the-Queen-Derks-Ellemers/36f358f03c3d18e1ce17a03b585781888db94fa8

Derks, B., Van Laar, C., ve Ellemers, N. (2016). The queen bee phenomenon: Why women leaders distance themselves from junior women. The Leadership Quarterly, 27(3), 456-469. Erişim 20 Mayıs 2021, https://www.sciencedirect. com/science/article/pii/S1048984315001551

Dökmen, Z. (2010). Toplumsal Cinsiyet Sosyal Psikolojik Açıklamalar. İstanbul: Remzi Kitabevi

Esitlikçi reklamlariçin kurulan unstereotype alliance Türkiye'nin ilk genel kurul toplantısı gerçekleşti. (17 Kasım 2020). Erişim 21 Ocak 2021 www.rvd.org.tr/ haberler - a

García González, A. ve Piñeiro-Otero, T. (2011). Women in advertising production. Study of the Galician advertising sector from a gender perspective. Revista Latina de Comunicación Social, 66, 505-525. Erişim 20 Ekim 2020, https://www. researchgate.net/publication/268150362_Women_in_advertising_production_ Study_of_the_Galician_advertising_sector_from_a_gender_perspective 
Goldman, R., Heath, D. ve Smith, L. S. (1991). Commodity Feminism. Critical Studies in Mass Communication. 8. Erişim 14 Nisan 2019, https://www.tandfonline.com/doi/abs/10.1080/15295039109366801

Gregory, M.R. (2009). Inside the Locker Room: Male Homosociability in the Advertising Industry. Gender, Work \& Organization. 16. Erişim 15 Ekim 2020, https://onlinelibrary.wiley.com/doi/abs/10.1111/j.1468-0432.2009.00447.x

Haldankar, S. S., (2017). Moodboard: A Digital Solution for the Work-Life Balance in an Advertising Agency. Yayımlanmamış Yüksek Lisans Tezi. Rochester Institute of Technology.

Holmes, M. (2007). What is Gender?: Sociological Approaches. SAGE Publications.

Hülür, A. B. ve Kalafat Çat, A. (2018). Gıda reklamlarında kadının temsili. Abant Kültürel Araştırmalar Dergisi, 3(6): 1-12. Erişim 25 Eylül 2020, https://dergipark. org.tr/tr/pub/akader/issue/40154/414912

İktisadi Kalkınma Vakfı. (2019). AB Katıım Sürecindeki Türkiye'nin Kadın İstihdamı Karnesi, İstanbul: Dünya.

ILO. (2018). Çalışma Yaşamında Toplumsal Cinsiyet Eşitliği Eğitim Rehberi. Ankara: ILO

İşkur. (2015). Kadın İstihdam Eylem Planı 2016 - 2018. İstanbul.

Joyce, J. B., Hum , B., Ristimäki, H.-L., de Almeida, F. F., ve Doehring, A. (2021). Speaking out against everyday sexism: Gender and epistemics in accusations of "mansplaining.". Feminism \& Psychology. Şubat 2021. Erişim 5 Mart 2021, https://journals.sagepub.com/doi/full/10.1177/0959353520979499

KOÇ-KAM. (2019). Türkiye'de Toplumsal Cinsiyet Eşitliği 2019, İstanbul: Koç Üniversitesi.

Kuc, K. E. (2017). Gender dynamics in the advertising industry: the interplay of workplace culture and career advancement. Yayınlanmamış Sanatta Yeterlilik Tezi, Missouri-Columbia Üniversitesi.

Kurultay, A. (2019). Kristal Elma Yaratıcılık Festivalinde (1988-2018) Cam Tavan Olgusu: Kadın Jüri Üyesi Oranlarına Dair Bir İnceleme. Kültür ve İletişim. (44). Erişim 28 Eylül 2020, https://dergipark.org.tr/tr/pub/kulturveiletisim/issue/49260/629093

Lutzky, U., ve Lawson, R. (2019). Gender Politics and Discourses of \#mansplaining, \#manspreading, and \#manterruption on Twitter. Social Media + Society. Nisan 2019. Erişim 13 Mart 2020, https://journals.sagepub.com/ doi/10.1177/2056305119861807

Mallia, L.K. (2009). Rare Birds: Why So Few Woman Become Ad Agency Creative Directors. Advertising and Society Review. 10 / 3. Erişim 29 Eylül 2020, https:// www.researchgate.net/publication/236817724_Rare_Birds_Why_So_Few_Wo- 
men_Become_Ad_Agency_Creative_Directors

Mallia K. L. ve Windels, K. (2015). How Being Female Impacts Learning and Career Growth in Advertising Creative Departments. Employee Relations. 37. Erişim 29 Eylül 2020, http://dx.doi.org/10.1108/ER-02-2014-0011

McLeod, C., O'Donohoe, S. ve Townley, B. (2011). Pot Noodles, Placements and Peer Regard: Creative Career Trajectories and Communities of Practice in the British Advertising Industry. British Journal of Management. 22. Erişim 15 Ekim 2020, https://onlinelibrary.wiley.com/doi/abs/10.1111/j.1467-8551.2010.00705.x

Oğuz, G. (2013). Güzellik Kadınlar İçin Nasıl Vaade Dönüşür: Kadın Dergilerindeki Kozmetik Reklamları Üzerine Bir İnceleme. Selçuk İletişim, 6 (3), 184-195. Erişim 23 Mayıs 2020, https://dergipark.org.tr/tr/pub/josc/issue/19021/200626

Özdemir, M . (2010). Nitel Veri Analizi: Sosyal Bilimlerde Yöntembilim Sorunsalı Üzerine Bir Çalışma. Eskişehir Osmangazi Üniversitesi Sosyal Bilimler Dergisi, 11 (1) , 323-343 . Erişim 24 Mayıs 2021, https://dergipark.org.tr/en/pub/ogusbd/ issue/10997/131612

Özkan, P. (01 Ekim 2019). Ajansların Kadın - Erkek Yönetici Nüfusu. Erişim 17 Mart 2020 https://mediacat.com/ajanslarin-kadin-erkek-yonetici-nufusu/

Padavic, I. (1991). The Re-Creation Of Gender In A Male Workplace. Symbolic Interaction. 14(3). Erişim 28 Eylül 2020, https://www.jstor.org/stable/10.1525/ si.1991.14.3.279? seq=1

Reklamda Toplumsal Cinsiyet Cinsiyet Eşitliği Yürütme Kurulumuzun Çalışmalarrını TÜSIAD toplantısında anlattık. (11 Temmuz 2018). Erişim 24 Mayıs 2020, www. rvd.org.tr/haberler - b

Salminen-Karlsson, M. (2006). Situating gender in situated learning. Scandinavian Journal of Management. 22 (1). Erişim 28 Eylül 2020, (http://www. sciencedirect. com/science/article/pii/S0956522105000771)

Solnit, R. (13 Nisan 2008). Men who explain things. Los Angeles Times. Erişim 20 Ekim 2020, https://www.latimes.com/archives/la-xpm-2008-apr-13-op-solnit13-story.html

Thompson-Whiteside, H., Turnbull, S., ve Howe-Walsh, L. (2020) Advertising: should creative women be expected to 'fake it?', Journal of Marketing Management, 37 (3-4). Erişim 09 Ocak 2021. https://www.tandfonline.com/action/showCitFormats?doi=10.1080\%2F0267257X.2019.1707704

Türkiye'deki Effie ödüllü Televizyon Reklamlarının 10 Yıllık Toplumsal Cimsiyet Eşitliği Karnesi Araştırması Raporu. (22 Ekim 2018). Erişim 24 Mayıs 2020, www. rvd.org.tr/haberler - c

Ügümü Aktaş, P. (2018). Toplumsal Cinsiyete Dair Değişimlerin Reklamlara Yansimasi: Kadinlara Yönelik Reklamlara Göstergebilimsel Bir Bakış. Stratejik ve Sosyal Araştırmalar Dergisi. 2 (3). Erişim 23 Mayıs 2021, https://dergipark.org.tr/tr/ 
pub/sisad/issue/40334/457222

van Het Hof, S.D. ve Hoştut, S. (2016). Pembe Getto: Türkiye'de Kurumsal İletişim Yöneticileri. Fe Dergi: Feminist Eleştiri. 8, no. 2. Erişim 25 Eylül 2020, https:// cins.ankara.edu.tr/16_8.pdf

WEForum. (2020). Global Gender Gap Report 2020. İsviçre: World Economic Forum.

West, C. ve Zimmerman D.H. (1987). Doing Gender. Gender and Society. 1 (2). Erişim 20 Mayıs 2020, https://www.jstor.org/stable/189945?seq=1 